\title{
ECOSYSTEM SERVICES VALUE: CASE OF POLLINATION
}

\author{
Janusz Majewski ${ }^{1}$, PhD eng. \\ ${ }^{1}$ Department of Agricultural Economics and International Economic Relation, Warsaw University \\ of Life Sciences - SGGW
}

\begin{abstract}
Ecosystem services constitute inseparable component of human life. Their economic value is difficult to estimate. Estimating the economic value of the ecosystem services is important because it is necessary to make people realise the importance of the natural environment. The study attempts to present the pollination as an ecosystem service. The purpose of the study was to specify the market and non-market components of valuation of pollination as well as estimating the economic value of the service for the main crops in Poland.

Pollination of open-pollinated plants is necessary for their reproduction. In Poland, the plant species pollinated by insects account for approx. $78 \%$ open-pollinated plant species. They include many arable crops. The most important Polish entomophilious arable crops include the fruit plants, rape, colza, shrubs and permanent pasture, buckwheat and vegetables: tomatoes and cucumbers. The value of pollination of the plants in Poland estimated by means of the method of the value of production generated thanks to pollination increased from EUR 625 million in 2005 to EUR 1195 million in 2016. The growth resulted both from the growth of the area of the crops and the growth in the prices of buying-in prices of most of the entomophilious plants. In the structure of the value of pollination, prevailed fruit plants, accounting for $55 \%$ of the value of pollination on average of the total plants under review in 2005-2016. The value of pollination of rape and colza amounted to $21 \%$ on average; of fruit shrubs and permanent crops: $14.5 \%$; tomatoes and ground cucumbers: $7.5 \%$, and buckwheat: over $2 \%$.

The method of estimating the pollination value of open-pollinated plants should be developed, in particular those related to the economic value of wild plants. In particular, the foregoing follows from the need of compensation for the ecosystem services performed, e.g. by honey bees of the apicultural farms, and also imposition and enforcement of fines if the natural environment is destroyed.
\end{abstract}

Key words: ecosystem services, pollination, economic value of pollination, Poland.

JEL code: E01, Q51, Q57.

\section{Introduction}

The nature (the ecosystem) and the goods and services generated by the nature are of fundamental importance for human life. The economic value of the nature lies in choices that humans make (Zylicz, 2017). The value of the nature is perceived by the value of the so-called ecosystem services. In order to continue its development, the world economy has to overcome the ecologic barrier, i.e. responsibly use the natural environment (Rutkowska-Podolowska, Poplawski, 2015). This, in turn, points to the need of valuation of the environmental goods and services. We should bear in mind the limitations applicable to monetary valuation of goods and services of this kind, in particular due to their complexity (Fiedor, 2017).

Ecosystem services may be defined as their contribution to human well-being (Braat, de Groot, 2012). On the other hand, Boyd and Banzhaf (2007, p. 619) provided the following definition of the ecosystem services: "Final ecosystem services are components of nature, directly enjoyed, consumed, or used to yield human well-being." We can distinguish between the market and non-market value of the ecosystem services (Boyd, Banzhaf, 2007), depending on whether the service can be evaluated on the market or not. The study of Constanza et al. (1997) was a groundbreaking work concerning the value of nature, specifying 17 key ecosystem services along with their economic value (USD 33 trillion $\left(33^{*} 10^{12}\right.$ ) annually on average) above the annual global GDP. This pointed to the importance of the ecosystem services as indispensable for human life.

Pollination is one of the ecosystem services. The study presents an attempt to characterize pollination performed by insects as an ecosystem service, specifying the market and non-market 
components of the value of this ecosystem service, and the economic value of pollination of arable crops in Poland. The study employs the literature analysis method, as well as the dependence ratio method with regard to valuation of the economic value of pollination of the arable crops.

\section{Research results and discussion 1. Pollination benefits}

The natural environment provides many services, which can be divided into the following groups: provisioning, cultural, supporting and regulating ones (Schowalter et al., 2017). Insects, which are an important component of the natural environment, play the key role in the creating and regulating of many ecosystem services (Stein et al., 2017). Pollination is one of the most important ecosystem services performed by insects (Noriega et al., 2017).

Pollination is necessary to obtain fruit or seeds. Depending on the origin of the pollen serving for pollination, we can distinguish self-pollinating and open-pollinating plants Self-pollinating plants use pollen from the same flower or another flower of the same plant for pollination, while openpollinating plants need pollen from another plant of the same species for pollination. However, even in the case of autogamous species, cross-pollination allows obtaining finer fruit and seeds. Open-pollinating plants need an external factor for pollination, which, under the natural condition, can include wind, water, or animals (predominantly insects). According to estimations, the majority (approx. $78 \%$ ) of open-pollinating plants in Poland is pollinated by insects, while approx. $22 \%$ of the plants are pollinated by wind (Koltowski and Jablonski, 2008).

Honey bee is one of the most important pollinating insects in the world. Its importance grows due to increasingly large arable areas which prevent wild pollinating insects access to the plants, pollution of the natural environment, inappropriate use of plant protection products and other chemicals in agriculture and reduction of non-productive areas. All those factors negatively contribute to the number of wild insects in the natural environment, and in addition to the honey bee, also solitary bees and bumble bees, in particular with regard to crops cultivated under shelter (Hanley et al., 2015). Also, other insects are important for pollination of plants, since many insect pollinated plants must be pollinated by specific insect species in order to yield seeds (Garratt et al., 2014), which follows from co-evolution of the organisms.

Insect pollination as an ecosystem service provides many benefits to mankind, whether directly or indirectly. The opportunity of obtaining crops should be considered as the primary benefit. Pollination allows obtaining crops of fruit or seeds of open-pollinating plants or at least is the factor increasing the number and quality of the crops (Kremen et al., 2007, Klatt et al., 2014, Melathopoulos et al., 2015, Stewart et al., 2017). In particular, the influence of the pollinating insects on the arable crops was discussed in particular by Morse and Calderone (2000) and Losey and Vaughan (2006). The immediate benefits also include the continuance of diversity, since absence of pollinators prevents open-pollinating plants from reproduction which results in changes in the natural environment in the form of extinction of the plant. As far as honey bee is concerned, the intermediate benefits include the possibility of obtaining bee products, such as honey, pollen, propolis, wax, apitoxin (bee venom) and royal jelly. The products may be included into human diet but they may also be used for medicinal or cosmetic purposes. In certain, usually less developed, countries insects may constitute food being a source of easily digestible protein. Pollinating insects also provide food for animals, in particular birds, thus contributing to their preservation. As far as the honey bee is concerning, it can be used as a bioindicator, due to their prevalence and 
accumulation of pollution in their organisms, which may be an indicator of the quality of the natural environment.

\section{Economic value of pollination}

It is difficult to estimate the economic value of pollination of plants. The effects of pollination of plants may be attributed to any of the ecosystem services groups distinguished by Schowalter et al. (2017).

In the source literature, publications prevail in which the pollination value has been estimated from the point of view of arable crops. They found out that approx. $35 \%$ of the global food production depends on insect pollination (Klein et al., 2007). The importance of pollinating insects for the global agriculture is growing. The surface area of arable crops has grown by more than $300 \%$ between 1961 and the first decade of the $21^{\text {st }}$ century (Aizen et al., 2008). The annual value of pollination of arable crops was estimated at USD 153 billion (Gallai et al., 2009). The value of pollination of arable crops in the European Union countries estimated by Gallai et al. (2009) and by Leonhardt et al. (2013) did not significantly differ (and amounted to EUR 14.2 and EUR 14.6 billion, respectively), which may mean that the method of estimation of the said value have been better developed. More results of works related to the estimation of the value of pollination of arable crops are presented in the study by Majewski (2017).

It is much more difficult to determine the value of pollination of wild plants. This is due to an absence of measurable effect and generation of so-called non-market goods. The goods are not present on the market, and, therefore, have no market price, which may raise controversies. For example, it is difficult to estimate the market value of a plant species, which will become extinct in the case of absence of its pollinating insects. In such a case, if the ecosystem service is public good, the services can be valued using direct or indirect techniques. In the event of indirect techniques, it applies to hypothetic markets on which specific good can be purchased or sold. The value of a service is determined by asking how much people would be willing to pay for specific good (willingness to pay - WTP), or how much they would ask to dispose of *(sell) the good (willingness to accept - WTA). On the other hand, as far as the indirect technique is concerned, the economic value is obtained by examining so-called substitute markets, on which goods that are complimentary to the good of interest are purchased and sold, provided that such markets exist.

In order to give picture of the economic value of pollination, estimation of the value for the main arable crops cultivated in Poland in 2005-2016 was performed. The study was based on the data collected by the Main Statistical Office (GUS) in Warsaw, the National Bank of Poland (NBP) and the source literature. The data provided by the Main Statistical Office were used to determine the production volume and the average buying-in prices of selected raw vegetable materials. The data obtained from the NBP concerned the average rates of foreign exchange and served the purpose of determining the pollination value in euro. The source literature provided the basis for determination of the participation of insect pollination in the yielded crops.

The most important insect pollinated arable crops cultivated in Poland were separated for the study: i.e. rape and colza, buckwheat, fruit plants (apple, pear, plum, cherry and sour cherry trees), shrubs and permanent crops (currants, gooseberry, strawberry and raspberry) and vegetables (tomatoes and cucumbers). The dependence ratio method was used to estimate the pollination value of the crops. Simplicity is an advantage of this method, since the value is calculated as a product of the value of production of specific plant and coefficient of the influence of 
pollination on the crop volume (e.g. if the coefficient is 0.6 it means that $60 \%$ of the value of production was obtained thanks to pollination). However, a problem related to this method is the determination of the effects of pollination and their valuation. The source literature often presents varying opinions concerning the extent of the influence of pollination on the yield of arable crops. This is attributable to multiplicity of factors affecting the crop volume, a part of which cannot be controlled by humans. It should also be noted that pollination is a specific procedure since it contributes to crop generating potential of plants. The potential may only be augmented but not created by other agro-technical procedures such as fertilisation, plant protection. On the other hand, natural factors, like frosts, hailstorms, absence or excessive precipitation may prevent or limit the yielding of crops. Selection of unit prices of seeds and fruit yielded thanks to pollination is also a certain problem. In the study, the buying-in prices of the agricultural crops were assumed.

Economic value of pollination of the main crops in Poland in 2005-2016

Table 1 (EUR million)

\begin{tabular}{|l|c|c|c|c|c|c|c|c|}
\hline Description & $\mathbf{2 0 0 5}$ & $\mathbf{2 0 1 0}$ & $\mathbf{2 0 1 1}$ & $\mathbf{2 0 1 2}$ & $\mathbf{2 0 1 3}$ & $\mathbf{2 0 1 4}$ & $\mathbf{2 0 1 5}$ & $\mathbf{2 0 1 6}$ \\
\hline Rape and colza & 83.7 & 214.2 & 249.1 & 264.8 & 282.3 & 310.5 & 291.5 & 247.0 \\
\hline Buckwheat & 9.6 & 27.0 & 32.2 & 19.9 & 19.3 & 19.0 & 32.1 & 49.9 \\
\hline Apples & 266.6 & 300.6 & 512.0 & 502.2 & 657.5 & 403.7 & 584.9 & 484.5 \\
\hline Pears & 15.0 & 16.7 & 19.6 & 22.1 & 22.7 & 20.9 & 22.1 & 25.5 \\
\hline Plums & 16.2 & 17.5 & 21.4 & 28.6 & 21.3 & 14.0 & 22.7 & 20.5 \\
\hline Sour cherries & 82.0 & 84.5 & 95.9 & 129.3 & 93.0 & 45.1 & 63.4 & 54.3 \\
\hline Cherries & 19.8 & 54.0 & 43.6 & 53.5 & 47.7 & 59.8 & 54.0 & 48.4 \\
\hline Strawberry & 10.3 & 17.8 & 31.0 & 31.4 & 23.3 & 24.1 & 24.6 & 27.3 \\
\hline Raspberry & 29.7 & 70.3 & 60.4 & 71.0 & 118.0 & 115.0 & 118.6 & 126.1 \\
\hline Currants & 24.2 & 64.0 & 112.0 & 58.2 & 50.1 & 23.1 & 20.9 & 33.6 \\
\hline Gooseberry & 4.4 & 4.9 & 8.4 & 9.9 & 8.2 & 6.8 & 3.8 & 2.6 \\
\hline Cucumbers $*$ & 61.6 & 72,0 & 70.9 & 83.9 & 87.4 & 78.9 & 76.0 & 67.5 \\
\hline Tomatoes * & 2.9 & 5.8 & 6.2 & 7.9 & 9.7 & 10.9 & 10.2 & 8.5 \\
\hline Total & $\mathbf{6 2 5 . 9}$ & $\mathbf{9 4 9 . 3}$ & $\mathbf{1 2 6 2 . 6}$ & $\mathbf{1 2 8 2 . 9}$ & $\mathbf{1 4 4 0 . 5}$ & $\mathbf{1 1 3 1 . 6}$ & $\mathbf{1 3 2 4 . 9}$ & $\mathbf{1 1 9 5 . 8}$ \\
\hline
\end{tabular}

* - field crops were included.

Source: author's calculations based on Rolnictwo w 2016 r., 2017, Skup i ceny..., 2017 and Uzytkowanie gruntow i..., 2017 (Agriculture in 2006, 2017, Buying-in and prices ..., 2017 and Land use and ..., 2017)

The value of pollination of the main crops in Poland in 2005-2016 ranged from over EUR 625 million in 2005 to EUR 1440 million in 2013 (Table 1). In each of the years under review, apple trees were the most important arable plants from the point of view of pollination. Their pollination value ranged from nearly EUR 270 million in 2005 up to nearly EUR 660 million in 2013. The high value of pollination of the plant followed from adoption of high index of the influence of pollination on the crop volume (1.0). On the other hand, considerable variability of pollination of apple trees followed both from changes in the buying-in prices of apples in the years under review and from variability of the production volume.

The high value of pollination was also obtained in the case of rape and colza. The pollination value in 2011-2016 was approximately 3 - 4 times higher than in the initial year of the study. It was primarily the result of the growth of the surface area of cultivation of that plant, which was attributable to the growth in the demand for rape seeds from the industry, in particular the biofuel industry. Rape is important from the point of view of apiculture, since rape is a melliferous plant. The value of pollination of buckwheat was characterised by the highest dynamics. This was attributable to the considerable increase in the prices of buckwheat seeds in the period under 
review. Also the value of pollination of raspberry increased over 4 times both in terms of the growth of the cultivation area by nearly $100 \%$ and the buying-in prices which grew by over $130 \%$. However, in 2016, drops in the value of pollination of sour cherry and gooseberry were reported as compared to year 2005. In the case of the first plant, the latter was attributable to drop in the buying-in prices by over $50 \%$. On the other hand, drop in the pollination value of gooseberry was mainly attributable to decrease in the area of its cultivation.

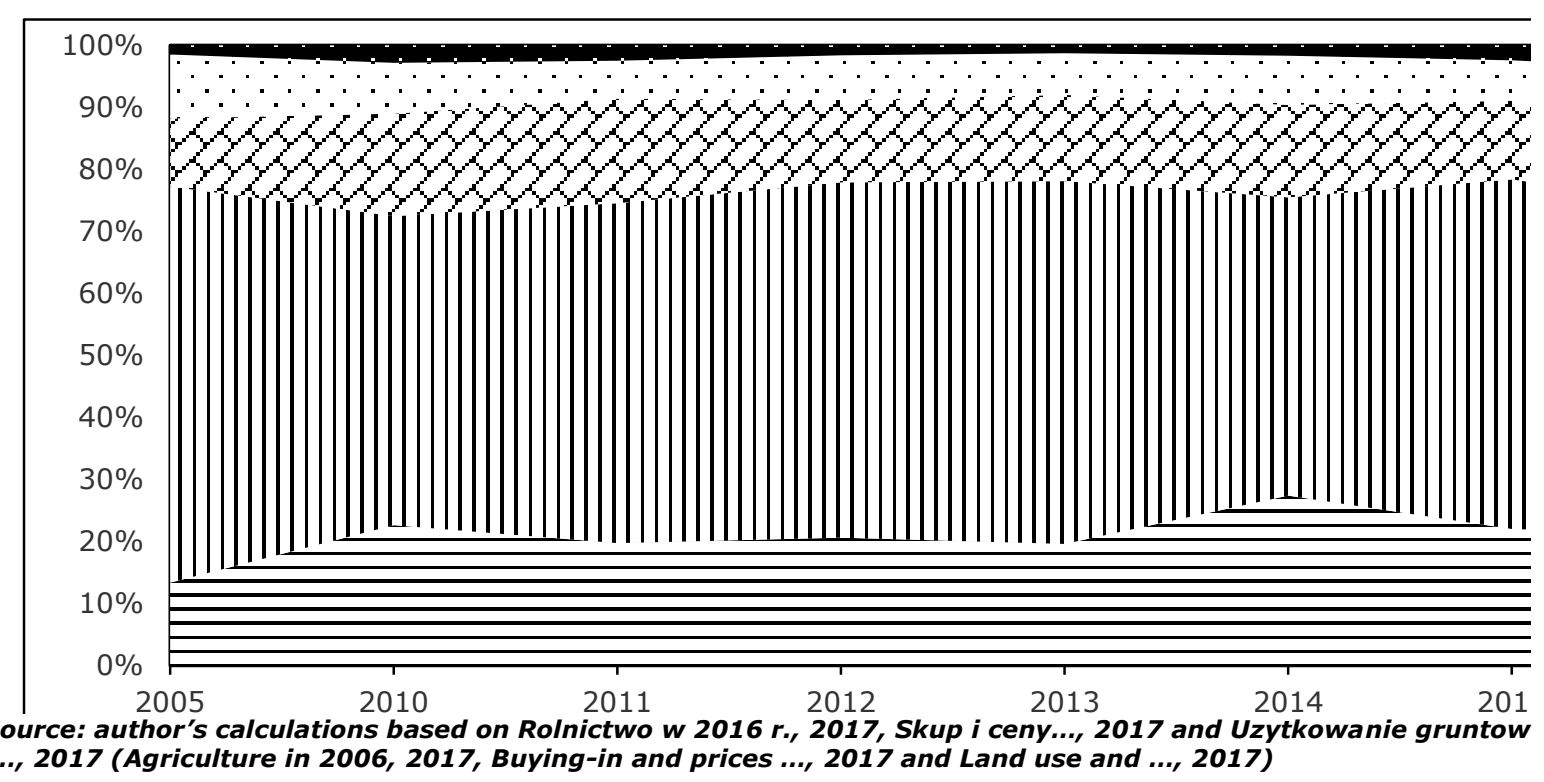

Fig. 1. The structure of the pollination needs of the most important arable crops in Poland in 2005-2016

In the economic structure of the value of pollination of arable crops in Poland in 2005-2016, the fruit plants were of the greatest importance (Fig. 1). Their pollination value ranged from nearly 400 to over EUR 840 million, and represented from $48 \%$ in 2014 to nearly $64 \%$ of the value of pollination of arable crops in 2005. Rape was an important plant from the point of view of the pollination value. Its share in the pollination value grew from $13.4 \%$ in 2005 to nearly $21 \%$ in 2016. This was attributable to a large extent form the growth in the area of cultivation of this plant in Poland. In the period under review, the value of pollination of fruit shrubs and permanent crops on average accounted for approx. $14 \%$ of the value of pollination of all the plants under review, with deviation by $+/-3$ percentage points. In the period under review, the share of the ground vegetables (tomatoes and cucumbers) dropped from over $10 \%$ in 2005 to approx. $6 \%$ in 2016, which was attributable to stagnation in the volume of the crops of the plants and negligible pace of growth in their prices.

\section{Conclusions and recommendation}

Pollination is the key ecosystem service due to its fundamental role in the reproduction of plants. The pollinating insects account for the key group of animals providing the service. In Poland, the pollinate approx. $78 \%$ of open-pollinated plants; therefore, the realistic determination of the economic value of the services is so important. The following conclusions and recommendations may be drawn and formulated on the basis of the research.

1) Pollination as the key ecosystem service performs both the supply role (which is a component of the food production process) and a supporting and regulative (plant reproduction) role, and also a cultural role (e.g. restoration of wild-bee keeping). 
2) Vast influence of the pollination on human life and the nature, including in particular production of public good makes it difficult to fully estimate the economic value of pollination.

3) In Poland, the economic value of pollination of the major arable crops grew from EUR 625.9 million in 2005 to EUR 1440.5 million in 2013. In the last year of the study (2016), the value amounted to EUR 1195.8 million

4) Changes in the pollination values were mainly attributable to changes in the cropped area and entomophilious plant crops, and also to variability in the prices of fruits and seeds obtained from the plants.

5) It seems reasonable that in the methods of pollination of the open-pollinated plants the aspect of change of prices as a result of growth/drop in the production of specific goods should be taken into account to a greater extent. Also, importance should be attached to improvement in the quality of agricultural products achieved thanks to pollination. However, from the point of view of determining the value of pollination of wild plants, research should be continued to improve the estimation methods.

\section{Bibliography}

1. Aizen, M.A., Garibaldi, L.M., Cunnigham, S.A., Klein, A.M. (2008). Long Term Trends in Crop Yield and Production Reveal no Current Pollination Shortage but Increasing Pollination Dependency, Current Biology, 18(20), 1572-1575. http://dx.doi.org/10.1016/j.cub.2008.08.066.

2. Boyd, J., Banzhaf, S. (2007). What Are Ecosystem Services? The Need for Standardized Environmental Accounting Units, Ecological Economics 63, pp. 616-626.

3. Braat, L.C., de Groot R. (2012). The Ecosystem Services Agenda: Bridging the Worlds of Natural Science and Economics, Conservation and Development, and Public and Private Policy, Ecosystem Services 1, pp. 415.

4. Constanza, R., d'Arge, R., de Groot, R., Farber, S., Grasso, M., Hannon, B., Limburg, K., Naeem, S., O'Neill, R.V., Paruelo, J., Raskin, R.G., Sutton, P., van den Belt, M. (1997). The Value of the World's Ecosystem Services and Natural Capital, Nature, vol. 387, pp. 253-260.

5. Fiedor, B. (2017). Istota i wartosciowanie kapitalu naturalnego w ujeciu ekonomii ekologicznej (Essence and Valuation of Natural Capital from Ecological Economics Persperdtive), Research Papers of Wroclaw University of Economics 491, pp. 136-145.

6. Gallai, M., Salles, J.M., Settele, J., Vaissiere, B.E. (2009). Economic Valuation of the Vulnerability of World Agriculture Confronted with Pollinator Decline, Ecological Economics 68, pp. 810-821.

7. Garratt, M.P.D., Coston, D.J., Truslove, C.L., Lappage, M.G., Polce, C., Dean, R., Biesmeijer, J.C, Potts, S.G. (2014). The Identity of Crop Pollinators Helps Target Conservation for Improved Ecosystem Services, Biological Conservation 169, pp. 128-135.

8. Hanley, N., Breeze, T.D., Ellis, C., Goulson, D. (2015). Measuring the Economic Value of Pollination Services: Principles, Evidence and Knowledge Gaps, Ecosystem Services 14, pp. 124-132.

9. Klatt, B.K., Holzschuh, A., Westphal, C., Clough, Y., Smit, I., Pawelzik, E., Tscharntke, T. (2014). Bee Pollination Improves Crop Quality, Shelf Life and Commercial Value, Proceedings of the Royal Society B 281: 20132440. http://dx.doi.org/10.1098/rspb.2013.2440.

10. Klein, A.M., Vaissiere, B.E., Cane, J.H., Steffan-Dewenter, I., Cunningham, S.A., Kremen, C., Tscharntke, T. (2007). Importance of Pollinators in Changing Landscapes for World Crops, Proceedings of the Royal Society B: Biological Sciences 274, pp. 303-313.

11. Koltowski, Z., Jablonski, B. (2008). Botanika pszczelarska (Beekeeping botany). In: J. Wilde and J. Prabucki, eds. Hodowla pszczol (Bee breeding), PWRiL, pp. 431-480.

12. Kremen, C., Williams, N.M., Aizen, M.A., Gemmill-Herren, B., LeBuhn, G., Minckley, R., Packer, L., Potts, S.G., Roulston, T., Steffan-Dewenter, I., Vazquez, D.P., Winfree, R., Adams, L., Crone, E.E., Greenleaf, S.S., Keitt, T.H., Klein, A.-M., Regetz, J., Ricketts, T.H. (2007). Pollination and Other Ecosystem Services Produced by Mobile Organizms: a Conceptual Framework for the Effects of Land-Use Change, Ecology Letters 10, pp. 299-314.

13. Leonhardt, S.D., Gallai, N., Garibaldi, L.A., Kuhlmann, M., Klein, A.M. (2013). Economic Gain, Stability of Pollination and Bee Diversity Decrease from Southern to Northern Europe, Basic and Applied Ecology 14(6), pp. 461-471.

14. Losey, J.E., Vaughan, M. (2006). The Economic Value of Ecological Services Provided by Insects, BioScience 56(4), pp. 311-323.

15. Majewski, J. (2017). Beekeeping Support in European Union Countries. Scientific Papers Series Management, Economic Engineering in Agriculture and Rural Development vol. 17, is. 4, pp. 193-197. 
16. Melathopoulos, A.P., Cutler, G.Ch., Tyedmers, P. (2015). Where is the Value in Valuing Pollination Ecosystem Services to Agriculture? Ecological Economics 109, pp. 59-70.

17. Morse, R.A., Calderone, N.W. (2000). The Value of Honey Bees as Pollinators of U.S. Crops in 2000, Bee Culture 128, pp. 1-15.

18. Noriega, J.A., Hortal, J., Azcarate, F.M., Berg, M.P., Bonada, N., Briones, M.J.I., Del Toro, I., Goulson, D., Ibanes, S., Landis, D.A., Moretti, M., Potts, S.G., Slade, E.M., Stout, J.C., Ulyshen, M.D., Wackers, F.L., Woodcock, B.A., Santos, A.M.C. (2017). Research Trends in Ecosystem Services Provided by Insects, Basic and Applied Ecology, http://dx.doi.org/10.1016/j.baae.2017.09.006.

19. Rolnictwo w 2016 r. (Agriculture in 2016) (2017). GUS, 180 p. Retrived: https://stat.gov.pl/obszarytematyczne/rolnictwo-lesnictwo/rolnictwo/rolnictwo-w-2016-roku,3,13.html. Access: 12.01.2018.

20. Rutkowska-Podolowska, M., Poplawski L. (2015). Wspolczesny kapitalizm a ochrona srodowiska (Contemporary Capitalism and Environmental Protection), Studia i Prace WNEiZ no 41, t. 2, pp. 75-83.

21. Schowalter, T.D., Noriega, J.A., Tscharntke, T. (2017). Insect Effects on Ecosystem Services - Introduction, Basic and Applied Ecology, http://dx.doi.org/10.1016/j.baae.2017.09.011.

22. Skup i ceny produktow rolnych w 2016 r. (Procurement and Prices of Agricultural Products in 2016) (2017). GUS, 51 p. Retrived: https://stat.gov.pl/en/topics/agriculture-forestry/agriculture/procurement-and-pricesof-agricultural-products-in-2016,5,3.html. Access: 12.01.2018.

23. Stein, K., Coulibaly, D., Stenchly, K., Goetze, D., Porembski, S., Lindner, A., Konate, S., Linsenmair, E.K. (2017). Bee Pollination Increases Yield Quantity and Quality of Cash Crops in Burkina Faso, West Africa, Scientific Reports vol. 7(1): 17691, DOI:10.1038/s41598-017-17970-2.

24. Stewart, R.I.A., Andersson, G.K.S., Bronkmark, Ch., Klatt, B.K., Hansson, L.-A., Zulsdorff, V., Smith, H.G. (2017). Ecosystem Services Across the Aquatic-Terrestrial Boundary: Linking Ponds to Pollination, Basic and Applied Ecology 18, pp. 13-20.

25. Uzytkowanie gruntow i powierzchnia zasiewow w 2016 r. (Land Use and Sown Area in 2016) (2017). GUS 103 p. Retrived: https://stat.gov.pl/obszary-tematyczne/rolnictwo-lesnictwo/rolnictwo/uzytkowaniegruntow-i-powierzchnia-zasiewow-w-2016-r-,8,11.html. Access: 12.01.2018.

26. Zylicz, T. (2017). Wartosc ekonomiczna przyrody (Economic Value of Nature), Zarzadzanie Publiczne no 1(39), pp. 114-124. 